\title{
How much forest protection is needed?
}

\author{
Forest protection specialists can expect many \\ searching questions about the size of benefits \\ from their programs in relation to costs of \\ research and operations
}

\section{J. HARRY G. SMITH}

Faculty of Forestry

University of British Columbio

Vancouver
The need to develop improved methods for damage appraisal and a desire for better understanding of the economics of forest protection are illustrated with some data on forest fires in British Columbia, 1912-1968. Fire suppression and general protection costs have increased very rapidly in recent years and may already have exceeded a level that can be justified easily, economically.

It is impossible to say how much forest protection is needed in Canada because no national survey of damage exists to define losses from attacks of insects, disease, and animals, and from extremes of climate. Even the forest fire damage statistics are not easily interpreted, economically. Only timber values have been estimated and damage appraisal methods in use should be improved (Mactavish 1966).

Changing ideas about values, methods of reporting, and systems of accounting further complicate the situation. In British Columbia, for example, B.C. Forest Service appraisal tables are in need of revi- sion and since the 1965/6 fiscal year costs of forest protection and management have been grouped. Also it does not seem feasible to determine costs, damages, and success in fire control separately for the "private and other agency" component of fire costs in British Columbia. We have no comparative data such as those reported annually by the Division of Cooperative State and Private Fire Control of the US Forest Service from which to draw reassurance about the utility of our efforts in fire control. The burned portions of US protected forest areas in 1968 were $0.19 \%$ on 650 million acres of Federal land, and $0.33 \%$ on 486 million acres of State and Private lands. Area burned represented $4.88 \%$ of 29 million acres of unprotected forest area in the United States.

Although Canadian interest in the economics of fire control is increasing, much remains to be accomplished (Mactavish 1965, Williams 1969). It would be helpful to undertake new studies for Can-

TABLE 1. Some British Columbia forest protection statistics, 1912-68

$$
\text { 1912-19 1920-29 1930-39 } 1940-49 \quad 1950-59^{1} \quad 1960-68^{1}
$$

No. fires.

Area burned, $\mathrm{M}$ acres.

(n)

Total damage, $\$ M$

Suppression costs

B.C.S. SM...

Others, $\$$ M.

Protection costs

B.C.F.S., \$M

Others, \$M.

B.C.F , revenues, $\$ M$

\begin{tabular}{|c|c|c|c|c|c|}
\hline $\begin{array}{l}961 \\
218 \\
123 \\
283\end{array}$ & $\begin{array}{r}1,866 \\
547 \\
709 \\
1,138\end{array}$ & $\begin{array}{r}1,669 \\
440 \\
756 \\
980\end{array}$ & $\begin{array}{r}1,554 \\
302 \\
401 \\
643\end{array}$ & $\begin{array}{r}1,614 \\
434 \\
1,300 \\
1,753\end{array}$ & $\begin{array}{r}2,250 \\
248 \\
3,150 \\
3,513\end{array}$ \\
\hline${ }^{62}$ & ${ }^{293}-$ & $\begin{array}{l}193 \\
101\end{array}$ & $\begin{array}{l}140 \\
113\end{array}$ & $\begin{array}{l}915 \\
345\end{array}$ & $\begin{array}{r}2,143 \\
572\end{array}$ \\
\hline 205 & 393 & $\begin{array}{l}330 \\
115\end{array}$ & $\begin{array}{l}801 \\
229\end{array}$ & $\begin{array}{r}2,381 \\
872\end{array}$ & $\begin{array}{l}3,800 \\
1,367\end{array}$ \\
\hline $\begin{array}{l}2.4 \\
1.4 \\
0.45\end{array}$ & $\begin{array}{l}3.8 \\
2.6 \\
0.60\end{array}$ & $\begin{array}{l}3.0 \\
2.5 \\
0.70\end{array}$ & $\begin{array}{l}5.4 \\
3.6 \\
0.95\end{array}$ & $\begin{array}{l}23.4 \\
5.5 \\
1.35\end{array}$ & $\begin{array}{r}41.0 \\
8.6 \\
1.80\end{array}$ \\
\hline
\end{tabular}

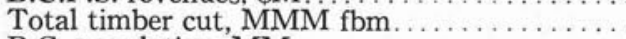

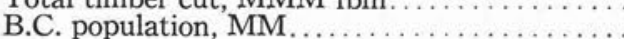

Approximate average annual values per period

${ }^{1}$ In these decades protection was extended to include northern B.C. 
TABLE 2. Some indices of efficiency of forest fire control in British Columbia, 1912-68

$$
\text { 1912-19 1920-29 } 1930-39 \quad 1940-49 \quad 1950-59 \quad 1960-68
$$

Average fire size, acres.

Total damage per fire, $\$$

Total suppression costs per fire, $\$$

Ratio of total damage to suppression plus protection costs, \$.

Damage plus suppression plus

protection costs, $\$ \mathrm{M}$.

protection costs, per $M$ fbm cut

No. fires per MM fbm cut

No. fires per MM population in B.C.

ada against a background of analyses of Provincial experience in forest fire control and use. Tables 1 and 2 have been prepared to illustrate the need for such work and to draw preliminary conclusions for British Columbia.

\section{Fire control in British Columbia}

Table 1 contains statistics which summarize some economic aspects of the forest protection situation in British Columbia since the Forest Service was established in 1912. In nearly six decades, number of fires reported annually has doubled. Area reported burned increased in the drought years of the 1920 's and then gradually decreased. Reported damage to forest cover has increased 24 times when the 1960's are compared with the 1910's. Suppression costs increased 480 times and, like protection costs, now include an important component of support from "other agencies". Protection costs have increased 250 times, B.C. Forest Service revenues 17 times, total timber cut 6 times, and population 4 times.

Logging commenced and settlements developed first on the South Coast and in the Southern Interior of the Province. In 1955 the Forest Service estimated that at least 100 million acres of the 165 million acres then in Forest Districts "must be afforded fire-protection in varying degrees of intensity". Forest districts and, therefore, protection against fire were not extended to cover the northern third of the Province until the 1950's. Because of uncertainty as to area actually protected, success of fire control cannot be measured conventionally, e.g. in terms of numbers of fires per million acres protected. For this and other reasons associated with changing definitions and methods it is impossible to interpret the data of Table 1 precisely. Yet some rough indices of efficiency of fire control can be derived for Table 2 . Increasingly efficient fire control has halved average fire size, but total damage per fire has increased 5 times, while direct suppression costs per fire increased 21 times. This suggests either that British Columbia has been spending too much money on suppression and protection or has been under-estimating the damage caused by fire. There is a clear need to improve estimates of "values at risk" (McNamara 1969).
Approximate average annual values per period

\begin{tabular}{ccccc}
293 & 264 & 194 & 269 & 110 \\
610 & 587 & 414 & 1,086 & 1,561 \\
157 & 176 & 163 & 781 & 1,327 \\
0.74 & 1.54 & 0.50 & 0.39 & 0.43 \\
& & & & \\
2,670 & 1,615 & 1,926 & 6,267 & 11,665 \\
1.04 & 0.64 & 0.54 & 1.15 & 1.36 \\
0.72 & 0.66 & 0.44 & 0.30 & 0.26 \\
3,110 & 2,384 & 1,636 & 1,196 & 1,250 \\
\hline
\end{tabular}

In recent decades the average protection dollar has reduced total damage in British Columbia by less than 50 cents. Since establishment of the B.C. Forest Service, total damage plus the sum of suppression and protection costs has increased 21 times. Fire damages plus suppression and protection costs expressed per $\mathrm{M}$ fbm cut have increased about three times. During this period the general wholesale price index fell in the 1920's and 1930's but increased to 282 in 1969 using $1935-39$ as 100 .

Numbers of fires per million fbm cut in the 1960's were only about $40 \%$ of those in the 1910's. Numbers of fires per million people in British Columbia have been reduced to about $60 \%$ of the 1910's level. These analyses should be localized, adjusted to a common degree of fire danger by use of multiple regression techniques, and expressed in probabilities of loss and cost. Mathematical modelling and simulation methods also should be used to refine decision making.

\section{Influences on hazard}

Speculations about what might have happened had there been no fire control are not quite futile. Hours of sunshine can indicate fire season severity (Turner 1970). Spring and summer precipitation can be correlated with numbers of fires and even extended back in time by tree ring analyses (Smith 1970). Such studies show that the 1920's and 1930 's were unusually dry and severe fire seasons. The reductions of hazard by slash burning and by changing methods of utilization must also be considered (Smith 1968, 1969). Simulation of forest fuels (Kurucz 1969) can contribute to an improved understanding, of what might have been, as a guide to what ought to be done. A particularly difficult aspect of any such studies is the need to live with extremely bad years such as 1922, 1929, 1931, 1940, 1958, 1961, and 1967 in British Columbia. In extreme years, averages may appear irrelevant.

\section{Fire losses from all causes}

In addition to a general lack of economic analysis there has been a tendency for Canadian forest fire prevention programs to fail to associate with the 
larger social problems of reduction of fire losses from all causes. For example, the Canada Yearbook for 1969 summarized fire losses 1957-66, excluding forest fires and Federal Government property losses. In 1966, a total of 68,463 fires destroyed 163 million dollars worth of property, cost Canadians $\$ 8.17$ each and killed 578 people. The principal cause of fires was smokers' carelessness $(32.3 \%)$. Lightning caused 2,407 fires (3.5\%). In 1966 lightning fires in dwellings were considerably more numerous than lightning caused forest fires in Canada.

\section{Benefit/cost analyses}

With the current emphasis of planning programming and budgeting systems, federally and provincially, forest protection specialists can expect many searching questions about the size of benefits from their programs in relation to costs of research and operations.

Forest protection planners, therefore, should initiate systems for collection and analysis of data on losses from all agents causing forest damage, and for evaluation of control benefits in relation to costs. Such information is badly needed to justify money spent on operations and research in relation to many other pressing demands for labour and capital. Unless "values at risk" of loss from fire are much greater than those presently estimated as fire dam-

\section{References cited}

B.C. FOREST SERVICE 1913 - 1969. Annual Reports, 1912 1968.

KURUCZ, J. 1969. Component weights of Douglas-fir, western hemlock, and western red-cedar biomass for simulation of amount and distribution of forest fuels. Fac. Forest., Univ. B.C., M. F. thesis, Mimeo. 116 p.

MACTAVISH, J. S. 1965. Economics and forest fire control. Can. Dep. Forest, Forest Res. Branch, Pub. No. 1114. 19 p. 1966. Appraising fire damage to mature forest stands. Can. Dep. Forest., Forest Res. Branch, Pub. No. $1162,31 \mathrm{p}$

McNAMARA, E. F. 1969. Concept and development of forest values at risk. Proceedings Northwest Forest Fire Council, Salem, Ore., 5-12. age, in British Columbia and other parts of Canada, it may well be that money could be used more efficiently in other aspects of forest resources management. It probably will be even harder to justify expenditures on protection from factors other than fire.

\section{Conclusions}

New protection standards should be established and implemented following careful economic analysis of past losses in relation to anticipated future benefits and costs. Important first steps would be development of improved indices of damage and a national system of estimating forest values lost annually to fire and other factors.

\section{Quel niveau de protection les forêts ont-elles besoin?}

A l'aide des données sur les feux de forêts qui se sont produits de 1912 à 1968 en Colombie-Britannique, l'auteur montre d'une part le besoin d'avoir de meilleures méthodes d'estimation des dommages et d'autre part, l'intérêt d'une compréhension accentuée sur l'économique de la protection des forêts. La répression des feux ainsi que les coûts de protection ont augmenté considérablement durant les dernières années, de sorte qu'ils ont vraisemblablement dépassé le niveau qui pouvait être facilement justifié et accepté économiquement.

SMITH, J. H. G. 1969. A summary of B.C. Forest Service annual reports on slash burning in B.C. 1912-68, with special reference to the Vancouver Forest District, 1937 68. Fac. Forest., Univ. B.C., Mimeo. 12 p.

1969. The future of prescribed burning in Western North America. Fac. Forest., Univ. B.C., Mimeo. 24 p.

1970. Review of tree-ring analyses in B.C. Univ. B.C., Fac. Forest. Proceedings of Conference on tree-ring analysis with special reference to Northwest America, Bull. 7.

TURNER, J. A. 1970. Hours of sunshine and fire season severity over the Vancouver Forest District. Forest. Chron. 46(2): 106-11.

WILLIAMS, D. E. 1969. Economics of forest fire control. Repr. from Pulp Paper Mag. Can. September. 2 p.

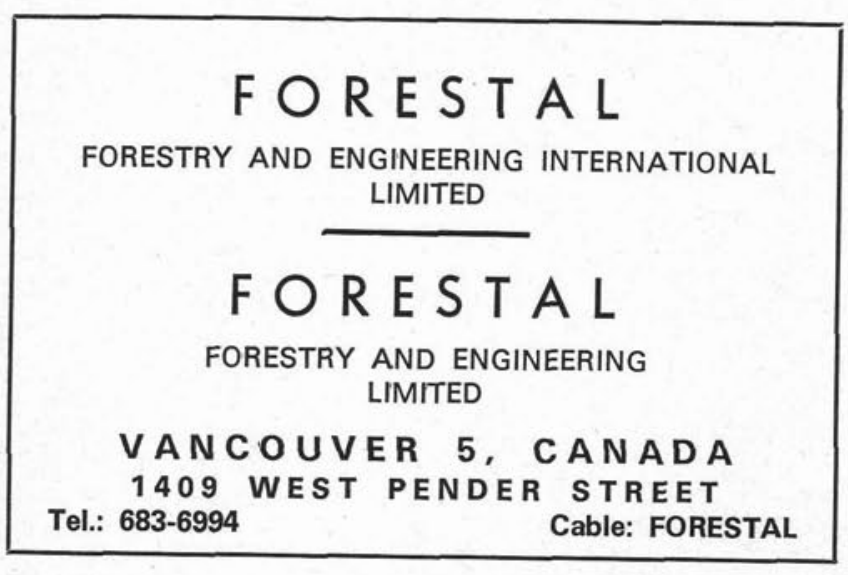

February 1971 The Forestry Chronicle

\section{CONSULTING}

FORESTERS \& ENGINEERS

\section{Industrial Forestry Service Ltd.}

1595 FIFTH AVE., PRINCE GEORGE, B. C.

TEL.: 563-9207 